УДК 664:66.011

DOI 10.29141/2500-1922-2020-5-3-6

\title{
Конструирование поликомпонентного
} кулинарного изделия для киберспортсменов

\author{
Ж.В. Новикова ${ }^{1}$, А.А. Максимкин ${ }^{1}$, С.М. Сергеева ${ }^{1 *}$, Е.В. Муханов ${ }^{1}$
}

${ }^{1}$ Московский государственный университет пищевых производств, г. Москва, Российская Федерация, *e-mail: sergeeva@mguрр.ги

\section{Ключевые слова: рыборастительное кулинарное изделие; рыборастительный фарш; \\ питание спортсменов; киберспорт; канихуа}

\begin{abstract}
Реферат
В настоящее время среди молодежи особую популярность приобретает киберспорт. Компьютерный спорт характеризуется существенными нагрузками на организм человека, в частности на физиологическое и психоэмоциональное состояние. От участников турниров требуется высокая степень концентрации и способность продолжительное время находиться за персональным компьютером. Указанные факторы обусловливают необходимость повышенного расхода энергии для поддержания организма в состоянии высокой активности. Для спортсменов по специальной технологии разрабатываются пищевые продукты на основе фундаментальных научных достижений в области спортивного питания. Высокая биологическая ценность пищевых продуктов для киберспортсменов делает их уникальными для поддержания активной жизнедеятельности в нестандартных условиях и при повышенных нагрузках в периоды подготовки и проведения соревнований. Для решения этой задачи авторами проведено математическое моделирование рецептуры поликомпонентного кулинарного изделия при помощи симплекс-метода и средств автоматизации с применением пакета программ MS Excel. Параметром оптимизации был выбран баланс незаменимых аминокислот. В результате математического моделирования получены восемь вариантов соотношений изменяемых ингредиентов, удовлетворяющих заданным условиям. Установлено, что замена хлеба пшеничного зернами канихуа улучшает сбалансированность аминокислот в белках комбинированных изделий. Органолептическая оценка кулинарного блюда «Биточки рыбные (паровые)», приготовленного по классической и разработанным рецептурам, позволила сделать вывод: внесение в рецептуру биточков свыше 34,0 \% зерна канихуа негативно отражается на вкусовых качествах изделия. Оптимизация рецептуры кулинарного изделия с использованием зерна канихуа позволила определить образцы поликомпонентных кулинарных изделий, которые соответствовали выбранным параметрам целевой функции.
\end{abstract}

\section{Multicomponent Culinary Products Development for Cybersportsmen}

\author{
Zhanna V. Novikova ${ }^{1}$, Anton A. Maksimkin ${ }^{1}$, Sophie M. Sergeeva ${ }^{*}$, Evgeny V. Mukhanov ${ }^{1}$ \\ ${ }^{1}$ Moscow State University of Food Production, Moscow, Russian Federation, *e-mail: sergeeva@mgupp.ru
}

\section{Keywords:}

fish and plant culinary product;

fish and plant mixture; meals for athletes;

\section{Abstract}

Currently, eSports becomes particularly popular among young people. Computer sport induces significant loads on the human body, especially on the physiological and psychoemotional state. Tournament participants are to have a high degree of concentration and the ability to stay at a personal computer for a long time. These factors determine the need for increased energy consumption to maintain the body in a state of high activity. 
eSports;

canihua
A man developed food products based on fundamental scientific achievements in the field of sports nutrition for athletes using special food technology. The high biological value of food products for eSports athletes makes them unique for maintaining active life in non-standard conditions and under increased loads during the preparation and conduct of competitions. To solve this problem, the authors performed mathematical modeling of the multicomponent culinary product recipe by the simplex method and automatization tools using the MS Excel software package. They chose the balance of essential amino acids as the optimization parameter. As a result of mathematical modeling, the researchers obtained eight ratios variants of the modified ingredients that meet the specified conditions. The replacement of bread wheat by the canihua is to improve the amino acids balance in proteins in the combined products. Organoleptic assessment of the culinary dish "Fish balls (steamed)», prepared according to the classic and developed recipes, allowed to conclude: the introduction of more than $34.0 \%$ of canihua grain into the recipe has a negative impact on the product taste. The recipe optimization of a culinary product using canihua grain approved samples determination of multicomponent culinary products that corresponded to the selected parameters of the target function.

For citation: Zhanna V. Novikova, Anton A. Maksimkin, Sophie M. Sergeeva, Evgeny V. Mukhanov. Multicomponent Culinary Products Development for Cybersportsmen. Индустрия numaния|Food Industry. 2020. T. 5, No. 3. Pp. 52-60. DOI: 10.29141/2500-1922-2020-5-3-6

Paper submitted: June 9, 2020

\section{Актуальность}

Сегодня в России в молодежной среде набирает популярность киберспорт (англ. eSports / electronic sports) - вид соревнований с использованием компьютерных технологий ${ }^{1}$. В 2017 г. компьютерный спорт был переведен во второй раздел Всероссийского реестра видов спорта - «Виды спорта, развиваемые на общероссийском уровне» ${ }^{2}$. Киберспорт - одно из быстроразвивающихся и перспективных направлений digital-индустрии. Только в нашей стране он привлекает аудиторию, превышающую 10 млн человек, одновременно являющихся и спортсменами, и зрителями, но с разной степенью вовлечения и активности (в том числе физиологической) [1].

В Олимпийской классификации видов спорта по характеру двигательной деятельности и по особенностям предмета состязаний киберспорт относится к пятой группе - «Виды спорта, основанные на абстрактно-логическом обыгрывании

\footnotetext{
${ }^{1}$ Приказ от 29 апреля 2016 г. № 470 «О признании и включении во Всероссийский реестр видов спорта спортивных дисциплин, видов спорта и внесении изменений во Всероссийский реестр видов спорта, а также в приказ Министерства спорта, туризма и молодежной политики Российской Федерации от 17 июня 2010 г. № 606 «О признании и включении видов спорта, спортивных дисциплин во Всероссийский реестр видов спорта».

${ }^{2}$ Приказ Министерства спорта России от 16 марта 2017 г. № 183 «О признании и включении во Всероссийский реестр видов спорта спортивных дисциплин, видов спорта и внесении изменений во Всероссийский реестр видов спорта».
}

соперника». По типу и интенсивности физической нагрузки киберспорт характеризуется как низкодинамический и среднестатический $[2 ; 3]$.

Несмотря на кажущуюся простоту, компьютерный спорт заметно влияет на организм человека. Уровень успеха в киберспорте в большей степени обусловлен не физическим напряжением, а эмоциональным состоянием спортсменов, что, в свою очередь, предполагает поддержание оптимального уровня гормонов и регулирование биологического состояния их организма. Основным недостатком данного вида спорта является малоподвижный образ жизни участников, что связано с продолжительными и беспрерывными тренировками и турнирами, проходящими в режиме реального времени. Особую опасность для киберспортсменов представляют «тунельный сидром», гиподинамия, вызывающая развитие сердечно-сосудистых заболеваний, расстройство нервной системы, нарушение обмена веществ, изменение функций опорно-двигательного аппарата [4, с. 19-37].

Полностью исключить травмы и проблемы со здоровьем киберспортсменов невозможно, но их можно свести к минимуму.

Оптимальный режим питания - один из способов сохранения здоровья киберспортсменов; его следует разрабатывать в соответствии их физиологическим состоянием, с учетом антропометрических особенностей организма и уровня двигательной активности. 
Наука о питании спортсменов стремительно развивается; ученые, занимающиеся спортивной нутрициологией, ведут исследования по вопросам профилактики и пропаганды здорового образа жизни [5]. Изучению проблем пищевого статуса спортсменов посвящен ряд работ ученых как в России, так и за рубежом.

Теоретическое обоснование рациональной структуры питания спортсменов представлено в работах таких известных отечественных ученых, как Н.К. Артемьева, М.Н. Волгарев Н.Д. Гольберг, А.П. Лаптев, В.Г. Лифляндский, Г.А. Макарова, З.Г. Орджоникидзе, В.М. Позняковский, С.А. Полиевский, А.А. Покровский, Н.А. Поляев, С.Л. Португалов, А.И. Пшендин В.А. Рогозкин, И.А. Рогов, Р.Д. Сейфулла, В.М. Смульский, Р.С. Суздальский, Э.С. Токаев, В.А. Тутельян и др.

Однако сегодня еще остаются не решенными ряд актуальных вопросов в области разработки рецептур продуктов для спортсменов [6].

От качества питания спортсмена зависят его физическая форма, а также способность организма к восстановлению [7]. Одним из способов решения проблем несбалансированного питания киберспортсменов является разработка новых продуктов специализированного назначения и совершенствование их технологий.

С учетом вышеизложенного целью данного исследования являлось конструирование поликомпонентного кулинарного изделия для включения в рацион питания киберспортсменов.

\section{Объекты и методы исследования}

Объектами исследования послужили:

1) полуфабрикат рыбного кулинарного изделия «Биточки рыбные (паровые)», выработанный по традиционной рецептуре № 282 Сборника рецептур блюд и кулинарных изделий [8];

2) полуфабрикаты рыборастительные из модельных фаршей, разработанные на кафедре индустрии питания, гостиничного бизнеса и сервиса Московского государственного университета пищевых производств (МГУПП).

При составлении рецептур, сбалансированных по составу, использовалось сырье животного и растительного происхождения: в качестве животного сырья - филе рыбы мороженое (ГОСТ 3948-2016', филе минтая); в качестве растительного сырья - зерна канихуа (СТО 96140533-035$2018^{2}$ ) - травянистого однолетнего растения высотой до 60 см. Канихуа (Kañihua, Kañiwa) является зрелым семенем Chenopodium pallidicaule. Размер семян в диаметре - от 0,5 до 1,5 мм; цвет

\footnotetext{
${ }^{1}$ ГОСТ 3948-2016. Филе рыбы мороженое. Технические ус ловия. М.: Стандартинформ, 2016.14 с.

${ }^{2}$ СТО 96140533-035-2018. Super Food Fortuche. Канихуа, зерно.
}

- темно-красно-коричневый или черный; форма слегка сжатая, грушевидная. Растение произрастает на высоте более 3800 м в Андских нагорьях Перу и Боливии.

Решение оптимизационных задач осуществляли симплекс-методом, т. е. путем построения базисных решений с монотонно убывающим линейным функционалом, до ситуации, когда выполняются необходимые условия локальной оптимальности.

Органолептические показатели кулинарного изделия «Биточки рыбные (паровые) с канихуа» оценивали по 5-балльной шкале.

\section{Результаты исследования и их обсуждение}

Выбор продуктов, включаемых в рацион питания киберспортсменов, зависит от характера и объема тренировочных и соревновательных нагрузок, а также от потребности их организма в пищевых веществах и энергии в разные периоды тренировочного процесса. В соответствии с особенностями обмена веществ в организме при различных тренировочных режимах требуется сохранять в рационе оптимальное количество нутриентов за счет изменения количественной и качественной характеристик питания [9].

Рубленые полуфабрикаты из рыбы обладают хорошими потребительскими свойствами, имеют достаточно высокую пищевую и биологическую ценность, но их состав не всегда позволяет обеспечить сбалансированное и профилактическое питание спортсменов.

Принимая во внимание относительно высокую пищевую (клетчатка, витамины) и биологическую ценность, выражающуюся в содержании незаменимых аминокислот, считаем, что зерна канихуа могут быть использованы в качестве обогащающей пищевой добавки к блюдам рыбной кулинарии.

Изучение пищевой ценности сырья. Для обоснования возможности использования зерен канихуа в производстве продукции общественного питания необходимым этапом является изучение пищевой ценности растительного сырья. Сравнение пищевой ценности рыбных и растительных ингредиентов приведено в табл. 1.

Пищевая ценность зерен канихуа по многим показателям, в том числе по содержанию белка на 6,89\%, жира - на 4,89 \%, суммарному содержанию витаминов группы В - на 34,67 \%, превосходит пшеничный хлеб. Замена пшеничного хлеба на зерна канихуа позволит обогатить производимые кулинарные изделия витаминами группы В и минеральными веществами, а также улучшить аминокислотный состав белка, что влияет на восстановление организма киберспортсменов после перенесенного эмоционального напря- 
Таблица 1. Химический состав сырья ${ }^{1}$ [10]

Table 1. Chemical Composition of the Raw Material [10]

\begin{tabular}{|c|c|c|c|}
\hline Показатель & Минтай & Хлеб пшеничный & Зерна канихуа \\
\hline \multicolumn{4}{|c|}{ Пищевая ценность, г/100 г } \\
\hline Вода & 81,90 & 38,70 & 11,30 \\
\hline Белки & 15,90 & 7,51 & 14,40 \\
\hline Жиры & 0,90 & 0,81 & 5,70 \\
\hline Углеводы & - & 51,38 & 63,60 \\
\hline Зола & 1,30 & 1,60 & 5,00 \\
\hline \multicolumn{4}{|c|}{ Аминокислотный состав, мг/г белка } \\
\hline Валин & 90,00 & 34,80 & 42,00 \\
\hline Изолейцин & 110,00 & 31,80 & 34,00 \\
\hline Лейцин & 130,00 & 59,40 & 61,00 \\
\hline Лизин & 180,00 & 18,90 & 53,00 \\
\hline Треонин & 65,80 & 23,10 & 33,00 \\
\hline Триптофан & 20,00 & 7,20 & 9,00 \\
\hline Фенилаланин + тирозин & 130,00 & 55,50 & 60,00 \\
\hline Метионин + цистеин & 75,00 & 26,10 & 46,00 \\
\hline \multicolumn{4}{|c|}{ Минеральный состав, мг/100 г } \\
\hline Калий & 420,00 & 93,00 & 110,00 \\
\hline Кальций & 40,00 & 20,00 & - \\
\hline Магний & 55,00 & 14,00 & 197,00 \\
\hline Фосфор & 240,00 & 65,00 & 375,00 \\
\hline Марганец & 100,00 & 1613,00 & - \\
\hline \multicolumn{4}{|c|}{ Витаминный состав, мг/100 г } \\
\hline $\mathrm{B}_{1}$ (тиамин) & 0,11 & 0,11 & 0,80 \\
\hline $\mathrm{B}_{2}$ (рибофлавин) & 0,11 & 0,03 & 0,50 \\
\hline $\mathrm{B}_{4}$ (холин) & - & 37,80 & 70,20 \\
\hline В 5 (пантотеновая кислота) & - & 0,19 & 0,80 \\
\hline $\mathrm{B}_{6}$ (пиридоксин) & 0,10 & - & 0,50 \\
\hline В9 (фолиевая кислота), мкг & - & - & 184,00 \\
\hline
\end{tabular}

жения в периоды подготовки и участия в соревнованиях. Влияние некоторых нутриентов на функциональные системы организма киберспортсменов представлено в табл. 2.

Недостаток белка в организме человека по сравнению с суточными физиологическими потребностями приводит к тому, что белки тканей внутренних органов вовлекаются в биохимические процессы, а образующиеся аминокислоты расходуются на синтез биологически активных соединений, ферментов и гормонов [11]. Для предотвращения подобных нежелательных процессов необходимо употреблять в пищу поликомпонентные продукты, в которых с максимальной эффективностью использовались бы все аминокислотные преимущества каждого ингредиента [12; 13]. С этой целью было проведено

\footnotetext{
${ }^{1}$ CTO 96140533-035-2018. Super Food Fortuche. Канихуа, зерно.
}

конструирование поликомпонентного кулинарного изделия, имеющего в своем составе рыбное и растительное сырье. В качестве функции желательности был выбран такой параметр, как баланс незаменимых аминокислот.

Задачу оптимизации рецептуры решали с помощью симплекс-метода и средств автоматизации с применением пакета программ MS Excel.

Постановка задачи проектирования рецептур блюд из минтая. В качестве искомых переменных использовались показатели массы, г:

$X_{1}-$ минтая;

$X_{2}$ - зерен канихуа;

$X_{3}$ - воды;

$X_{4}$ - яйца куриного;

$X_{5}$ - соли пищевой.

Количество ингредиентов $X_{3}, X_{4}, X_{5}$ рецептуры не изменялось, однако учитывался их химический состав. 
Таблица 2. Влияние нутриентов на функциональные системы организма киберспортсменов [9] Table 2. Nutrients Influence on the Functional Systems of eSports Players [9]

\begin{tabular}{|c|c|c|c|}
\hline Нутриент & Физиологическая роль нутриента & $\begin{array}{c}\text { Функциональная система } \\
\text { организма }\end{array}$ & $\begin{array}{c}\text { Суточная } \\
\text { потребность }\end{array}$ \\
\hline Лизин & $\begin{array}{l}\text { Регулирует уровень серотонина в крови; преду- } \\
\text { преждает стрессы, синдром хронической устало- } \\
\text { сти и нервные расстройства; повышает концент- } \\
\text { рацию внимания }\end{array}$ & Нервная система & $\begin{array}{c}12 \text { мг/кг } \\
\text { массы тела }\end{array}$ \\
\hline Метионин & $\begin{array}{l}\text { Является предшественником цистеина и таурина; } \\
\text { известен своими антиоксидантными свойствами }\end{array}$ & $\begin{array}{l}\text { Сердечно-сосудистая } \\
\text { система }\end{array}$ & $\begin{array}{c}13 \text { мг/кг } \\
\text { массы тела }\end{array}$ \\
\hline Триптофан & $\begin{array}{l}\text { Основная функция активного вещества в орга- } \\
\text { низме - повышение уровня серотонина и регуля- } \\
\text { ция работы нервной системы }\end{array}$ & Нервная система & $\begin{array}{c}\text { 3,5 мг/кг } \\
\text { массы тела }\end{array}$ \\
\hline Магний & $\begin{array}{l}\text { Обладает успокаивающим воздействием; помо- } \\
\text { гает при переутомлении }\end{array}$ & $\begin{array}{c}\text { Нервно-мышечная } \\
\text { и сердечно-сосудистая } \\
\text { системы }\end{array}$ & $400 \mathrm{Mr}$ \\
\hline $\begin{array}{l}\text { Витамин } B_{2} \\
\text { (рибофлавин) }\end{array}$ & $\begin{array}{l}\text { Стимулирует производство энергии в клетках; } \\
\text { способствует нормальному функционированию } \\
\text { органов пищеварения }\end{array}$ & $\begin{array}{l}\text { Пищеварительная } \\
\text { система }\end{array}$ & $1,8 \mathrm{Mr}$ \\
\hline $\begin{array}{l}\text { Витамин } \mathrm{B}_{9} \\
\text { (фолиевая } \\
\text { кислота) }\end{array}$ & Необходим для кровеносной и иммунной систем & $\begin{array}{l}\text { Кровеносная и иммунная } \\
\text { системы }\end{array}$ & 400 мкг \\
\hline
\end{tabular}

Ограничения по долям ингредиентов:

$$
\begin{aligned}
0,417 \leq & X_{1} \leq 0,642 ; \\
0,144 \leq & X_{2} \leq 0,370 ; \\
X_{3} & =0,160 ; \\
X_{4} & =0,040 ; \\
X_{5} & =0,004 .
\end{aligned}
$$

Ограничения по весу полуфабриката:

$$
X_{1}+X_{2}+X_{3}+X_{4}+X_{5}=1
$$

Ограничения по содержанию нутриентов в рецептуре представлены в табл. 3.

В процессе компьютерного и/или математического моделирования получены восемь вари- антов соотношений изменяемых ингредиентов, удовлетворяющих заданным условиям. Ниже приведены результаты компьютерного моделирования рыборастительных композиций (табл. 4; см. рисунок).

Как видно из диаграммы, наилучший баланс аминокислотного состава имеет место в вариантах рецептур, содержащих большее количество растительного компонента.

Показатели пищевой и биологической ценности контрольного образца и рыборастительных композиций приведены в табл. 5.

Таблица 3. Оптимизация рецептуры по содержанию нутриентов Table 3. Recipe Optimization for the Nutrients Content

\begin{tabular}{l|l}
\multicolumn{1}{c|}{ Параметр } & \multicolumn{1}{c}{ Ограничение } \\
\hline Валин, мг/г белка & $X_{1}+X_{2}+X_{3}+X_{4}+X_{5} \geq 50$ \\
\hline Изолейцин, мг/ г белка & $X_{1}+X_{2}+X_{3}+X_{4}+X_{5} \geq 40$ \\
\hline Лейцин, мг/ г белка & $X_{1}+X_{2}+X_{3}+X_{4}+X_{5} \geq 70$ \\
\hline Лизин, мг/ г белка & $X_{1}+X_{2}+X_{3}+X_{4}+X_{5} \geq 55$ \\
\hline Метионин + цистин (серосодержащие), мг/г белка & $X_{1}+X_{2}+X_{3}+X_{4}+X_{5} \geq 35$ \\
\hline Треонин, мг/ г белка & $X_{1}+X_{2}+X_{3}+X_{4}+X_{5} \geq 40$ \\
\hline Триптофан, мг/г белка & $X_{1}+X_{2}+X_{3}+X_{4}+X_{5} \geq 10$ \\
\hline Феналаланин + тирозин (ароматические), мг/г белка & $X_{1}+X_{2}+X_{3}+X_{4}+X_{5} \geq 60$ \\
\hline Белки, г & $X_{1}+X_{2}+X_{3}+X_{4}+X_{5} \geq 14,72$ \\
Жиры, г & $X_{1}+X_{2}+X_{3}+X_{4}+X_{5} \geq 1,44$ \\
Углеводы, г & $X_{1}+X_{2}+X_{3}+X_{4}+X_{5} \geq 8,89$
\end{tabular}


Таблица 4. Результаты компьютерного моделирования рыборастительных композиций Table 4. Computer modeling results of Fish and Plant Mixture

\begin{tabular}{|l|c|c|}
\hline Сырье & Соотношение компонентов, \% & Значение целевой функции \\
\hline Рыба : хлеб (контроль) & $81: 19$ & 0,751 \\
& $81: 19$ & 0,758 \\
\hline Рыба : канихуа & $76: 24$ & 0,761 \\
& $71: 29$ & 0,765 \\
\hline & $66: 34$ & 0,768 \\
\hline
\end{tabular}

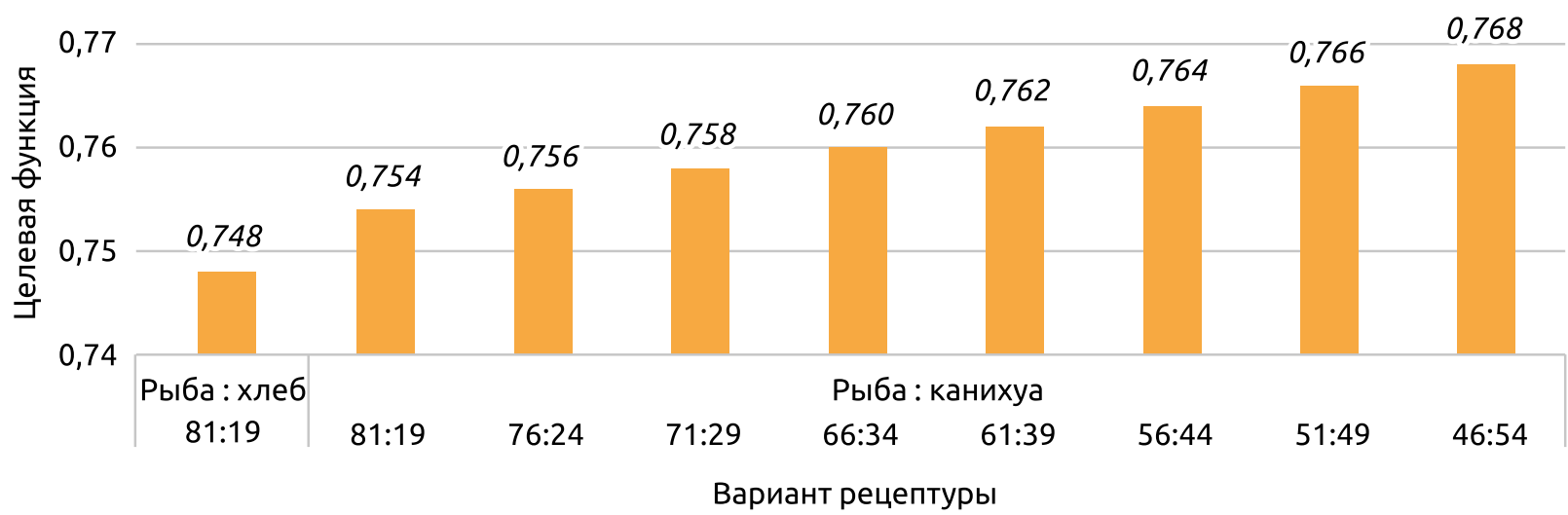

Значения целевых функций для рыборастительных композиций Objective Functions Values for Fish and Plant Mixtures

Таблица 5. Пищевая и биологическая ценность рыборастительных композиций (соотношение компонентов), \%

Table 5. Nutritional and Biological Value of Fish and Plant Mixtures (Components Ratio), \%

\begin{tabular}{|c|c|c|c|c|c|c|c|c|c|}
\hline \multirow{2}{*}{ Показатель } & \multirow{2}{*}{$\begin{array}{c}\text { Рыба : хлеб } \\
81: 19\end{array}$} & \multicolumn{8}{|c|}{ Рыба : канихуа } \\
\hline & & $81: 19$ & $76: 24$ & $71: 29$ & $66: 34$ & $61: 39$ & $56: 44$ & $51: 49$ & $46: 54$ \\
\hline Валин, мг/г белка & 71,77 & 66,92 & 68,54 & 70,17 & 71,81 & 73,47 & 75,14 & 76,83 & 78,53 \\
\hline Изолейцин, мг/г белка & 85,21 & 78,71 & 80,13 & 81,57 & 83,01 & 84,47 & 85,94 & 87,43 & 88,93 \\
\hline Лейцин, мг/г белка & 104,74 & 96,62 & 98,97 & 101,32 & 103,70 & 106,11 & 108,53 & 110,98 & 113,45 \\
\hline Лизин, мг/г белка & 135,02 & 128,29 & 130,54 & 132,79 & 135,07 & 137,37 & 139,69 & 142,03 & 144,40 \\
\hline $\begin{array}{l}\text { Метионин + цистин } \\
\text { (серосодержащие), мг/г белка }\end{array}$ & 59,68 & 57,27 & 58,97 & 60,68 & 62,40 & 64,14 & 65,89 & 67,66 & 69,45 \\
\hline Треонин, мг/г белка & 52,32 & 49,32 & 50,58 & 51,84 & 53,12 & 54,41 & 55,70 & 57,02 & 58,34 \\
\hline Триптофан, мг/г белка & 15,95 & 14,89 & 15,25 & 15,60 & 15,96 & 16,32 & 16,68 & 17,05 & 17,42 \\
\hline $\begin{array}{l}\text { Феналаланин + тирозин } \\
\text { (ароматические), мг/г белка }\end{array}$ & 104,41 & 96,64 & 98,96 & 101,29 & 103,64 & 106,01 & 108,40 & 110,82 & 113,26 \\
\hline Белки, г & 13,88 & 15,08 & 15,01 & 14,94 & 14,87 & 14,80 & 14,73 & 14,66 & 14,59 \\
\hline Жиры, г & 2,77 & 3,58 & 3,79 & 4,00 & 4,21 & 4,42 & 4,62 & 4,83 & 5,04 \\
\hline Углеводы, г & 8,51 & 10,96 & 13,84 & 16,69 & 19,55 & 22,41 & 25,26 & 28,12 & 30,97 \\
\hline
\end{tabular}


Для всех представленных вариантов рецептур скор незаменимых аминокислот превышает $100,0 \%$, что свидетельствует о их высокой биологической ценности.

Следующий этап - проектирование поликомпонентных рецептур с использованием такого сырья, как минтай, зерна канихуа, яйцо куриное, вода, соль пищевая. Соотношение ингредиентов в полученных вариантах представлено в табл. 6.

В результате оптимизации, проведенной с помощью симплекс-метода, было установлено, что замена хлеба пшеничного зернами канихуа приводит к улучшению сбалансированности аминокислот в белках комбинированных изделий. Целесообразность использования зерна канихуа подтверждается также наличием в их составе значительного количества витаминов, макро- и микроэлементов (см. табл. 1).

С целью определения оптимального количества вносимого компонента были приготовлены образцы биточков рыбных паровых по классической и модельным рецептурам, проведена органолептическая оценка готовых кулинарных изделий по средствам дегустации.

Эксперимент по органолептической оценке кулинарного изделия «Биточки рыбные (паровые)» проводился на группе лиц из числа обучающихся (три команды по 10 чел.), участвовавших в киберспортивном турнире «Кубок Ректора МГУПП» (дисциплины «Counter-Strike : Global Offensive», "Hearthstone», "League of Legends»), мужского пола, в возрасте 20-22 лет. Для органолептической оценки использовали универсальные 5-балльные шкалы (табл. 7).

Сравнительный анализ позволяет сделать вывод: образцы 5, 6, 7, 8-й получили более низкие оценки по органолептическим показателям, а именно: отмечены их непривлекательный внешний вид, крошащаяся текстура; образцы не сохраняли форму после тепловой обработки. Таким образом, внесение более 34,0 \% зерна канихуа в рецептуру кулинарного изделия «Биточки рыбные (паровые)» негативно отражается на его вкусовых качествах.

Таблица 6. Состав рыборастительных композиций (варианты)

Table 6. Composition of the Fish and Plant Mixtures (Variants)

\begin{tabular}{|c|c|c|c|c|c|}
\hline Вариант & Минтай & Зерно канихуа & Вода & Яйцо куриное & Соль пищевая \\
\hline Вариант 1 & 0,645 & 0,151 & \multirow{8}{*}{0,160} & \multirow{8}{*}{0,040} & \multirow{8}{*}{0,004} \\
\hline Вариант 2 & 0,605 & 0,191 & & & \\
\hline Вариант 3 & 0,565 & 0,231 & & & \\
\hline Вариант 4 & 0,525 & 0,271 & & & \\
\hline Вариант 5 & 0,486 & 0,310 & & & \\
\hline Вариант 6 & 0,446 & 0,350 & & & \\
\hline Вариант 7 & 0,406 & 0,390 & & & \\
\hline Вариант 8 & 0,366 & 0,430 & & & \\
\hline
\end{tabular}

Таблица 7. Органолептическая оценка модельных образцов

кулинарного изделия "Биточки рыбные (паровые)», балл

Table 7. Organoleptic Model Samples Assessment of the Culinary Product "Fish Balls (Steamed)", Score

\begin{tabular}{|c|c|c|c|c|c|c|c|c|c|}
\hline \multirow{2}{*}{ Показатель } & \multicolumn{9}{|c|}{ Образец } \\
\hline & Контроль & 1-й & $2-и ̆$ & 3-й & 4-й & 5-й & 6-й & 7-й & 8-й \\
\hline Вкус & 4,0 & 4,0 & 5,0 & 5,0 & 4,0 & 4,0 & 3,0 & 3,0 & 3,0 \\
\hline Форма & 5,0 & 5,0 & 5,0 & 5,0 & 4,0 & 3,0 & 3,0 & 2,0 & 2,0 \\
\hline Запах & 4,0 & 5,0 & 5,0 & 5,0 & 5,0 & 5,0 & 4,0 & 4,0 & 4,0 \\
\hline Текстура & 5,0 & 5,0 & 4,0 & 4,0 & 4,0 & 3,0 & 3,0 & 2,0 & 2,0 \\
\hline Внешний вид & 5,0 & 5,0 & 4,0 & 5,0 & 4,0 & 4,0 & 3,0 & 2,0 & 2,0 \\
\hline Итого, средний балл & 4,6 & 4,8 & 4,6 & 4,8 & 3,8 & 3,8 & 3,2 & 2,6 & 2,6 \\
\hline
\end{tabular}




\section{Выводы}

Разработка новых видов кулинарных изделий для питания киберспортсменов в периоды подготовки и проведения соревнований является актуальным направлением научных исследований и имеет важное социальное значение.

По мнению респондентов, участвовавших в дегустации разработанного поликомпонентного кулинарного изделия, образцы 3-й и 4-й, в состав которых минтай и зерна канихуа включены в со-

\section{Библиографический список}

1. Полиевский С.А. Основы индивидуального и коллективного питания спортсменов. М.: Физкультура и спорт, 2005. 384 с.

2. Матвеев Л.П. Основы спортивной тренировки. М.: Физкультура и спорт, 2007. 68 c.

3. Lemon, P.W. Effects of exercise on Protein Metabolism. Nutrition in Sport. Maugham, R.M. (Ed.). Blackwell Science Ltd., 2000. Pp.131-152. DOI: $10.1002 / 9780470693766 . c h 10$.

4. Уголев А.М, Иезуитова Н.Н. Идеальная пища и идеальное питание в свете новой науки трофологии // Наука и человечество: доступно и точно о главном в мировой науке. М.: Знание, 2009. C. 19-37.

5. Артемьева Н.К., Белина Н.Н., Лавриченко С.П. Общая нутрициология. Краснодар, 2015.87 с

6. Лобанов В.Г., Касьянов Г.И., Мазуренко Е.А. Особенности ре жима питания спортсменов игровых видов спорта // Вестник Воронежского государственного университета инженерных технологий. 2019. Т. 81, № 1. С. 160-167. DOI: 10.20914/2310-1202 2019-1-160-167.

7. Толмачев О.А., Австриевских А.Н., Быков А.Т., Позняковский В.М. Специализированный продукт для нутриентно-метаболической поддержки опорно-двигательной системы при занятиях физкультурой и спортом // Индустрия питания / Food Industry. 2019. T. 4, № 1. C. 14-22. DOI: 10.29141/2500-1922-2019-4-1-2.

8. Сборник рецептур блюд кулинарных изделий диетического питания: для предприятий общественного питания / под ред. Т.В. Лапшиной. М.: Хлебпродинформ, 2002. 632 с.

9. Рогозкин В.А., Пшендин А.И., Шишина Н.Н. Питание спортсменов. М.: Физкультура и спорт, 2009. 160 с.

10. Скурихин И.М., Тутельян В.А. Химический состав российских пищевых продуктов. М.: ДеЛи принт, 2007.236 с.

11. Ajuyah, A.O.; Fenton, T.W.; Hardin, R.T.; Sim, J.S. Measuring Lipid Oxidation Volatiles in Meats. Journal of Food Science. 2013. Vol. 58 Iss. 2. Pp. 270-273. DOI: 10.1111/j. 1365-2621. 1993. tb04253. x.

12. Тимошенко Н.В., Патиевой А.М., Патиевой С.В., Нестеренко А.А Функционально-технологические свойства мяса: метод. указания к лабораторно-практической работе. Краснодар: КубГАУ, 2014. 26 C.

13. Арансон М.В. Питание для спортсменов. М.: Физкультура и спорт, 2001. 244 c. отношении 2,5:1 и 1,9:1, отличаются более высокими органолептическими показателями.

Расчет пищевой ценности разработанного изделия с внесением 23,0 \% зерен канихуа от массы изделия покрывает рекомендуемую суточную норму физиологической потребности киберспортсменов: в лизине - на 130,0\%; магнии - на 19,0 \%; витамине $B_{2}$ - на 10,0 \%; витамине $B_{9}$ - на $46,0 \%$.

\section{Bibliography}

1. Polievskiy, S.A. Osnovy Individual'nogo i Kollektivnogo Pitaniya Sportsmenov [Fundamentals of Individual and Collective Nutrition of Athletes]. M.: Fizkul'tura i Sport. 2005. 384 p.

2. Matveev, L.P. Osnovy Sportivnoiy Trenirovki [Fundamentals of Sport Training]. M.: Fizkul'tura i Sport. 2007. 68 p.

3. Lemon, P.W. Effects of Exercise on Protein Metabolism. Nutrition in Sport. Maugham, R.M. (Ed.). Blackwell Science Ltd. 2000. Pp. 131-152. DOI: $10.1002 / 9780470693766 . c h 10$.

4. Ugolev, A.M.; Iezuitova, N.N. Ideal'naya Pishcha i Ideal'noe Pitanie v Svete Novoy Nauki Trofologii [Ideal Food and Ideal Nutrition in Terms of the New Science of Trofology]. Nauka i Chelovechestvo: Dostupno i Tochno o Glavnom v Mirovoi Nauke. M.: Znanie, 2009. Pp. 19-37.

5. Artemjeva, N.K.; Belina, N.N.; Lavrichenko, S.P. Obshchaya Nutriciologiya [Common Nutriciology]. Krasnodar. 2015. 87 p.

6. Lobanov, V.G.; Kasjyanov, G.I.; Mazurenko, E.A. Osobennosti Rezhima Pitaniya Sportsmenov Igrovyh Vidov Sporta [Nutrition Regime Features of Team Sports Athletes]. Vestnik Voronezhskogo Cosudarstvennogo Universiteta Inzhenernyh Tekhnologii. 2019. Vol. 81, no. 1. Pp. 160-167. DOI: 10.20914/2310-1202-2019-1-160-167.

7. Tolmachev, 0.A.; Avstrievskih, A.N.; Bykov, A.T.; Poznyakovskiiy, V.M. Specializirovannyi Produkt dlya Nutrientno-Metabolicheskoi Podderzhki Opornodvigatel'noi Sistemy pri Zanyatiyah Fizkul'turoi I Sportom [Specialized Product for Nutrient and Metabolic Support of the Musculoskeletal System in Physical Education and Sports]. Industriya Pitaniya / Food Industry. 2019. Vol. 4, no. 1. Pp. 14-22. DOI: 10.29141/2500-1922-2019-4-1-2.

8. Sbornik Receptur Blyud Kulinarnyh Izdelii Dieticheskogo Pitaniya: Dlya Predpriyatii Obshchestvennogo Pitaniya [Recipes Collection of Culinary Dietary Dishes: for Public Catering Enterprises]. pod red. T.V. Lapshinoi. M.: Hlebprodinform, 2002.632 p.

9. Rogozkin, V.A.; Pshendin, A.I.; Shishina, N.N. Pitanie Sportsmenov [Sportsmen Nutrition]. M.: Fizkul'tura i Sport, 2009. 160 p.

10. Skurihin, I.M.; Tutelyan, V.A. Himicheskii Sostav Rossiiskih Pishchevyh Produktov [Chemical Composition of Russian Food Products]. M.: Deli Print, 2007. 236 p.

11. Ajuyah, A.0.; Fenton, T.W.; Hardin, R.T.; Sim, J.S. Measuring Lipid Oxidation Volatiles in Meats. Journal of Food Science. 2013. Vol. 58, Iss. 2. Pp. 270-273. DOI: 10.1111/j. 1365-2621. 1993. tb04253. x.

12. Timoshenko, N.V.; Patievoy, A.M.; Patievoy, S.V.; Nesterenko, A.A. Funkcional'no-Tekhnologicheskie Svoistva Myasa [Functional and Technological Properties of Meat]: Metod. Ukazaniya k Laboratorno-Prakticheskoi Rabote. Krasnodar: KubGAU, 2014. 26 p.

13. Aranson, M.V. Pitanie dlya Sportsmenov [Nutrition for Athletes]. M.: Fizkul'tura i Sport, 2001. 244 p. 
Информация 06 авторах / Information about Authors

Новикова

Жанна Викторовна

Novikova,

Zhanna Viktorovna

тел./Phone: +7 (499) 750-01-11

E-mail:zh_novikova@mail.ru

\section{Максимкин \\ Антон Алексеевич \\ Maksimkin, Anton Alekseevich \\ тел./Phone: +7 (499) 750-01-11}

E-mail:aa.maksimkin@gmail.com

\section{Сергеева}

София Михайловна

Sergeeva,

Sophie Mikhailovna

Тел./Phone: +7 (499) 750-01-11

E-mail:sergeeva@mgupp.ru

\section{Муханов \\ Евгений Владимирович}

Mukhanov,

Evgeny Vladimirovich

Тел./Phone: +7 (499) 750-01-11 E-mail: mustdie.m192@gmail.com
Кандидат технических наук, доцент, профессор кафедры индустрии питания, гостиничного бизнеса и сервиса

Московский государственный университет пищевых производств 125080, Российская Федерация, г. Москва, Волоколамское шоссе, 11

Candidate of Technical Sciences, Associate Professor, Professor of the Food Industry, Hotel Business and Service Department

Moscow State University of Food Production

125080, Russian Federation, Moscow, Volokolamskoe Ave, 11

ORCID: https://orcid.org/0000-0001-8652-4777

Кандидат технических наук, дочент кафедры биотехнологии и технология продуктов биотехнологического синтеза

Московский государственный университет пищевых производств

125080, Российская Федерация, г. Москва, Волоколамское шоссе, 11

Candidate of Technical Sciences, Associate Professor of the Food Industry, Hotel Business and Service Department

Moscow State University of Food Production

125080, Russian Federation, Moscow, Volokolamskoe Ave, 11

ORCID: https://orcid.org/

Старший преподаватель кафедры индустрии питания, гостиничного бизнеса и сервиса

Московский государственный университет пищевых производств 125080, Российская Федерация, г. Москва, Волоколамское шоссе, 11

Senior Lecturer of the Food Industry, Hotel Business and Service Department Moscow State University of Food Production

125080, Russian Federation, Moscow, Volokolamskoe Ave, 11

ORCID: https://orcid.org/0000-0003-3873-6139

Студент

Московский государственный университет пищевых производств 125080, Российская Федерация, г. Москва, Волоколамское шоссе, 11

Student

Moscow State University of Food Production

125080, Russian Federation, Moscow, Volokolamskoe Ave, 11

ORCID: https://orcid.org/0000-0002-3379-2775 